\title{
Effects of Foliage Spraying with Sodium Bisulfite on the Photosynthesis of Orychophragmus violaceus
}

\author{
Zhongying Li ${ }^{1}$, Yanyou Wu ${ }^{2, *}$, , Deke Xing ${ }^{1}$, Kaiyan Zhang ${ }^{3}$, Jinjin Xie ${ }^{1}$, Rui Yu ${ }^{1}$, Tian Chen ${ }^{1}$ \\ and Rongrong Duan ${ }^{1}$
}

1 Key Laboratory of Modern Agricultural Equipment and Technology, Ministry of Education, Institute of Agricultural Engineering, Jiangsu University, Zhenjiang 212013, China; 2211816010@stmail.ujs.edu.cn (Z.L.); xingdeke@ujs.edu.cn (D.X.); 2211816002@stmail.ujs.edu.cn (J.X.); 2111316005@stmail.ujs.edu.cn (R.Y.); 2211916001@stmail.ujs.edu.cn (T.C.); 2211916002@stmail.ujs.edu.cn (R.D.)

2 Research Center for Environmental Bio-Science and Technology, State Key Laboratory of Environmental Geochemistry, Institute of Geochemistry, Chinese Academy of Sciences, Guiyang 550081, China

3 State Engineering Technology Institute for Karst Desertification Control, Guizhou Normal University, Guiyang 550001, China; kaiyanzhang@126.com

* Correspondence: wuyanyou@mail.gyig.ac.cn; Tel.: +86-851-84391746

check for updates

Citation: Li, Z.; Wu, Y.; Xing, D.; Zhang, K.; Xie, J.; Yu, R.; Chen, T.; Duan, R. Effects of Foliage Spraying with Sodium Bisulfite on the Photosynthesis of Orychophragmus violaceus. Horticulturae 2021, 7, 137. https: / / doi.org/10.3390/ horticulturae7060137

Academic Editor: Alessandra Francini

Received: 14 May 2021

Accepted: 4 June 2021

Published: 6 June 2021

Publisher's Note: MDPI stays neutral with regard to jurisdictional claims in published maps and institutional affiliations.

Copyright: (c) 2021 by the authors. Licensee MDPI, Basel, Switzerland. This article is an open access article distributed under the terms and conditions of the Creative Commons Attribution (CC BY) license (https:/ / creativecommons.org/licenses/by/ $4.0 /)$.

\begin{abstract}
Sulphurous acid derived from sulfur dioxide $\left(\mathrm{SO}_{2}\right)$ emission leads to the pollution of irrigation water and the inhibition of plant growth. The safe concentration threshold of $\mathrm{NaHSO}_{3}$ in plants should be clarified to promote agricultural production. In this study, Orychophragmus violaceus seedlings were used as experimental materials and five $\mathrm{NaHSO}_{3}$ concentrations (i.e., $0,1,2$, $5,10 \mathrm{mmol} \cdot \mathrm{L}^{-1}$ ) were simultaneously sprayed on the leaf surface of different seedlings separately. Leaf physiology responses under different concentrations were analyzed. The $\mathrm{NaHSO}_{3}$ did not promote photosynthesis in $O$. violaceus under the 1 and $2 \mathrm{mmol} \cdot \mathrm{L}^{-1}$ treatments. It was conducive to the net photosynthetic rate $\left(P_{N}\right)$, photorespiration rate $\left(R_{p}\right)$, chlorophyll content, actual photochemical quantum yield $\left(\mathrm{Y}_{\mathrm{II}}\right)$ and photochemical quenching $(\mathrm{qP})$ under the $5 \mathrm{mmol} \cdot \mathrm{L}^{-1}$ treatment. However, quantum yield of regulated energy dissipation $\left(\mathrm{Y}_{\mathrm{NPQ}}\right)$ and nonphotochemical quenching (NPQ) were inhibited. Under the $10 \mathrm{mmol} \cdot \mathrm{L}^{-1}$ treatment, $P_{N}$, chlorophyll content, $\mathrm{Y}_{\mathrm{II}}, \mathrm{qP}$, dark respiration rate $\left(R_{d}\right)$ and electron transport rate (ETR) showed significant decreases, while the photorespiration portion $\left(S_{p}\right)$ significantly increased. Our results demonstrated that $\mathrm{NaHSO}_{3}$ provided a sulfur source for plant growth and interfered with the redox reaction of the plant itself, and its role as a photorespiratory inhibitor might be masked.
\end{abstract}

Keywords: agricultural production; redox; photorespiration; chlorophyll fluorescence; dose effect

\section{Introduction}

Orychophragmus violaceus is a member of the family Brassicaceae that is widely used for beautifying the city and ecological restoration [1]. O. violaceus is also a healthy seasonal vegetable that can be eaten year round and is widely distributed, especially in Yunnan, Guizhou and other southern cities [2]. The plant species has high economic and ornamental value. Sulfur dioxide $\left(\mathrm{SO}_{2}\right)$ is a widely diffused air pollutant, which is easily dissolved in the water of rivers or lakes and which forms sulfite and sulfuric acid. If the water source polluted by $\mathrm{SO}_{2}$ is used for irrigation or spraying on greening plants, it may not be conducive to the plants' growth. Studies have shown that the toxicity of $\mathrm{SO}_{2}$ to plants was mainly attributed to the highly active intermediate bisulfite [3]. Katainen et al. has also reported that the treatment of sphagnum moss with $0.1 \mathrm{mmol} \cdot \mathrm{L}^{-1}$ of $\mathrm{H}_{2} \mathrm{SO}_{3}$ increased the net photosynthetic rate [4]. Therefore, $\mathrm{HSO}_{3}{ }^{-}$may have a two-way effect on the photosynthesis and growth of plants when it is used for irrigation.

$\mathrm{NaHSO}_{3}$ is one of the most commonly used sulfites, which can be used as a photosynthetic accelerator in agricultural production [5-8]. However, the effect of $\mathrm{NaHSO}_{3}$ on the 
photosynthetic growth of plants depends on its concentration. Studies have shown that $0.5 \mathrm{mmol} \cdot \mathrm{L}^{-1}$ of $\mathrm{NaHSO}_{3}$ is the best concentration to promote the photosynthetic oxygen release of Anabaena, while $1 \mathrm{mmol} \cdot \mathrm{L}^{-1}$ of $\mathrm{NaHSO}_{3}$ can increase the net photosynthetic rate of Satsuma mandarin by approximately $15 \%[9,10]$. In general, low concentrations of $\mathrm{NaHSO}_{3}$ $\left(<1 \mathrm{mmol} \cdot \mathrm{L}^{-1}\right)$ can significantly improve the photosynthetic oxygen release rate and dry matter accumulation of algae and other lower plants $[6,10,11]$, while most higher plants after low concentrations of $\mathrm{NaHSO}_{3}\left(<8 \mathrm{mmol} \cdot \mathrm{L}^{-1}\right)$ spraying can significantly enhance the photosynthetic carbon assimilation ability [7-9,12]. Bisulfite can represent a sulfur source for plants. Botryococcus braunii reportedly stopped growing after surviving for 12 days in a sulfur-free medium, but grew well under a bisulfite treatment of 0.1 or $0.8 \mathrm{mmol} \cdot \mathrm{L}^{-1}$ [6]. However, the promotion of plant growth by the addition of low concentrations of $\mathrm{NaHSO}_{3}$ is not just attributed to the supply of sulfur nutrients. At present, the effect of $\mathrm{NaHSO}_{3}$ on the photorespiration of plants is still controversial. Kang et al. [7] demonstrated that $5 \mathrm{mmol} \cdot \mathrm{L}^{-1}$ of $\mathrm{NaHSO}_{3}$ inhibited the photorespiration rate of Caragana korshinskii, and the content of glyoxylic acid decreased significantly. However, Chen et al. [8] found that photosynthetic and photorespiration rates increased simultaneously after soybean leaves were treated with $5 \mathrm{mmol} \cdot \mathrm{L}^{-1}$ of $\mathrm{NaHSO}_{3}$. Under normal conditions, photorespiration consumes approximately a quarter of the total output of photosynthesis and the portion of photorespiration will increase when the atmospheric carbon dioxide significantly affects the stomata [13]. In recent years, studies on the effects of foliar sprays of $\mathrm{NaHSO}_{3}$ on plants have mainly focused on the response of the photorespiration rate to $\mathrm{NaHSO}_{3}[7,8]$, whereas the proportion of photorespiration in total photosynthesis has not yet been reported. Therefore, variations in the portion of photorespiration must be determined when studying the photosynthetic physiological mechanism of $\mathrm{NaHSO}_{3}$ in plants. In addition, high concentrations of $\mathrm{NaHSO}_{3}\left(>8 \mathrm{mmol} \cdot \mathrm{L}^{-1}\right)$ can cause certain toxicity to the photosynthetic physiology of plants. Ten $\mathrm{mmol} \cdot \mathrm{L}^{-1}$ of $\mathrm{NaHSO}_{3}$ significantly decreased the net photosynthetic rate of strawberry leaves [9]. The photosynthetic electron transport of pea leaves was inhibited by high concentrations of sulfite [14]. It is interesting to note that $\mathrm{NaHSO}_{3}$ is a chemical compound with both oxidizing and reducing properties. Sulfite in plants can be reduced to sulfide by sulfite reductase or oxidized to sulfate by sulfite oxidase [15]. During photosynthesis, plants produce and accumulate different forms of reactive oxygen species (i.e., ROS) and reducing agents (i.e., ascorbic acid, thioredoxin and reduced glutathione), which are important regulators of photosynthesis-related gene expression [16]. Wei et al. showed that $\mathrm{HSO}_{3}{ }^{-}$could react with superoxide anion to form $\mathrm{SO}_{4}{ }^{2-}$ [17]. However, it has also been reported that $\mathrm{NaHSO}_{3}$ oxidation destroys the structure of algae cell membranes [18]. When $\mathrm{NaHSO}_{3}$, which has both oxidation and reduction properties, enters the plant, the normal redox reaction will be disturbed and indirectly affect photosynthesis. However, few reports have focused on the regulation of plant redox by $\mathrm{NaHSO}_{3}$.

O. violaceus was used as experimental material in this study, the mechanisms of different concentrations of $\mathrm{NaHSO}_{3}$ on photosynthesis were investigated, the safe concentration threshold of $\mathrm{NaHSO}_{3}$ in plant leaves was clarified and the theoretical basis for promoting agricultural production and reducing agricultural ecological environment pollution could be provided.

\section{Materials and Methods}

\subsection{Plant Culture and Treatment}

The experiment was carried out in the Key Laboratory of Modern Agricultural Equipment and Technology of the Ministry of Education, College of Agricultural Engineering, Jiangsu University $\left(\mathrm{N} 32^{\circ} 11^{\prime}\right.$ and $\left.\mathrm{E} 119^{\circ} 27^{\prime}\right)$. The seeds of $O$. violaceus were placed on wet gauze and germinated in a light incubator with a light intensity of $40 \mu \mathrm{mol} \cdot \mathrm{m}^{-2} \cdot \mathrm{s}^{-1}$. Water was sprayed every day to keep the gauze moist. The seeds were seeded in a 12-hole seedling tray with perlite and exposed to white light. Seedlings were cultivated in the tray with a small amount of 1/4-strength Hoagland solution until the 2 leaf stage. The culture 
conditions were as follows: photoperiod of $12 \mathrm{~h}, \mathrm{CO}_{2}$ concentration of $390 \pm 10 \mu \mathrm{mol} \cdot \mathrm{mol}^{-1}$, relative humidity of air of $60 \pm 5 \%$, day/night cycle temperature of $28{ }^{\circ} \mathrm{C} / 20^{\circ} \mathrm{C}$ and light intensity of $280 \pm 20 \mu \mathrm{mol} \cdot \mathrm{m}^{-2} \cdot \mathrm{s}^{-1}$.

After 45 days of growth, the leaves of different seedlings were sprayed with 0 (CK), $1\left(\mathrm{NS}_{1}\right), 2\left(\mathrm{NS}_{2}\right), 5\left(\mathrm{NS}_{3}\right)$ and $10\left(\mathrm{NS}_{4}\right) \mathrm{mmol} \cdot \mathrm{L}^{-1}$ of $\mathrm{NaHSO}_{3}$ solutions. The spraying was conducted from 9:00 to 10:00 in the morning. The $50 \mathrm{~mL} \mathrm{NaHSO}_{3}$ solution was sprayed on plants in each pot every 5 days, and the seedlings were sprayed $5 \mathrm{~cm}$ from the top in all directions. During the treatment period, the leaves of the seedlings were sprayed every 5 days for a total of 5 times, and the experiment was carried out 25 days after the spray treatment.

\subsection{Gas Exchange Measurements}

The third fully expanded leaves from the top were chosen for the gas exchange measurement at 9:00-12:00 a.m. on a sunny day. A portable LI-6400XT photosynthesis measurement system (LI-COR Inc., Lincoln, NE, USA) was used. The flow rate was set to $500 \mu \mathrm{mol} \cdot \mathrm{s}^{-1}$, and the leaf temperature was $30 \pm 2{ }^{\circ} \mathrm{C}$. The net photosynthetic rate $\left(P_{N}\right)$, stomatal conductance $\left(g_{s}\right)$, intercellular carbon dioxide $\left(C_{i}\right)$, transpiration rate $(E)$ and other photosynthetic parameters were selected from the two response curves under a light intensity of $800 \mu \mathrm{mol} \cdot \mathrm{s}^{-1}$ and a $\mathrm{CO}_{2}$ concentration of $400 \mu \mathrm{mol} \cdot \mathrm{mol}^{-1}$. The $P_{N^{-}}$PAR response curves were always fitted using the nonrectangular hyperbola equation [19], which is expressed as follows:

$$
P_{N}=\frac{\alpha I+A \max -\sqrt{(\alpha I+A \max )^{2}-4 \mathrm{k} \alpha I A \max }}{2 \mathrm{k}}-R_{d}
$$

where $P_{N}$ is the net photosynthetic rate $\left(\mu \mathrm{mol} \cdot \mathrm{m}^{-2} \cdot \mathrm{s}^{-1}\right)$; I is the photosynthetically active radiation $\left(\mu \mathrm{mol} \cdot \mathrm{m}^{-2} \cdot \mathrm{s}^{-1}\right.$ ); $\alpha$ (apparent quantum efficiency) is the initial slope of the $P_{N}$-PAR curves $\left(\mu \mathrm{mol} \cdot \mu \mathrm{mol}^{-1}\right)$; Amax is the net photosynthetic rate at light saturation $\left(\mu \mathrm{mol} \cdot \mathrm{m}^{-2} \cdot \mathrm{s}^{-1}\right) ; \mathrm{k}$ is the curve representing the degree of curvature of the curve angle, the value of which is $[0,1]$; and $R_{d}$ is the dark respiration rate $\left(\mu \mathrm{mol} \cdot \mathrm{m}^{-2} \cdot \mathrm{s}^{-1}\right)$. The atmospheric $\mathrm{CO}_{2}$ concentration during the measurement was $400 \mu \mathrm{mol} \cdot \mathrm{mol}^{-1}$. For every measurement, the PAR was set at 800, 600, 400, 300, 250, 200, 150, 100, and $50 \mu \mathrm{mol} \cdot \mathrm{m}^{-2} \cdot \mathrm{s}^{-1}$. After those photosynthetic parameters were acquired, the light saturation point (LSP) and light compensation point (LCP) for the photosynthetic capacity were obtained.

The $P_{N^{-}} C_{i}$ response curves were always fitted using the rectangular hyperbola equation [19], which is expressed as follows:

$$
P_{N}=\frac{C E B \max C i}{C E C i+B \max }-R_{t}
$$

where $P_{N}$ is the net photosynthetic rate $\left(\mu \mathrm{mol} \cdot \mathrm{m}^{-2} \cdot \mathrm{s}^{-1}\right) ; C E$ (carboxylation efficiency) is the initial slope of the $P_{N}$-PAR curves $\left(\mathrm{mol} \cdot \mathrm{m}^{-2} \cdot \mathrm{s}^{-1}\right) ; C_{i}$ is the intercellular $\mathrm{CO}_{2}$ concentration $\left(\mu \mathrm{mol} \cdot \mathrm{mol}^{-1}\right)$; Bmax is the net photosynthetic rate at $\mathrm{CO}_{2}$ saturation $\left(\mu \mathrm{mol} \cdot \mathrm{m}^{-2} \cdot \mathrm{s}^{-1}\right)$; and $R_{t}$ is the total respiratory rate $\left(\mu \mathrm{mol} \cdot \mathrm{m}^{-2} \cdot \mathrm{s}^{-1}\right)$. The photosynthetically active radiation during the measurement was $800 \mu \mathrm{mol} \cdot \mathrm{mol}^{-1}$. For every measurement, the $\mathrm{CO}_{2}$ concentration was set at 1500, 1200, 1000, 800, 600, 400, 350, 300, 250, 200, 100, and $50 \mu \mathrm{mol} \cdot \mathrm{mol}^{-1}$. After those photosynthetic parameters were acquired, the $\mathrm{CO}_{2}$ saturation point (CSP) and $\mathrm{CO}_{2}$ compensation point $(\mathrm{CCP})$ for the photosynthetic capacity were obtained.

The plant photorespiration portion was calculated as follows [20]:

$$
R_{p}=R_{t}-R_{d} ; P_{t}=P_{N}+R_{t} ; \text { and } \mathrm{S}_{p}=R_{p} / P_{t}
$$

where the definitions of $R_{d}$ and $R_{t}$ are the same as those in Formulas (1) and (2); $R_{p}$ was the photorespiration rate $\left(\mu \mathrm{mol} \cdot \mathrm{m}^{-2} \cdot \mathrm{s}^{-1}\right) ; P_{N}$ and $P_{t}$ are the net photosynthesis rate $\left(\mu \mathrm{mol} \cdot \mathrm{m}^{-2} \cdot \mathrm{s}^{-1}\right)$ and total photosynthetic rate $\left(\mu \mathrm{mol} \cdot \mathrm{m}^{-2} \cdot \mathrm{s}^{-1}\right)$ under specific $\mathrm{CO}_{2}$ concentrations and light intensities, respectively; and $S_{p}$ is the photorespiratory portion. 


\subsection{Chlorophyll-A Fluorescence (ChlF) Measurement}

The ChlF parameters were measured on the third fully expanded leaves from the top, which were the same leaves used for gas exchange measurements. Before the measurements, the leaves were dark-adapted for $30 \mathrm{~min}$ to ensure complete relaxation of all reaction centers. ChlF under dark adaptation was measured using a modulated chlorophyll fluorescence imaging system (IMAGING-PAM, Heinz Walz Gmbh) from 19:00 to 21:00. The minimum chlorophyll fluorescence $\left(F_{o}\right)$ was determined using a measuring beam, whereas the maximum chlorophyll fluorescence $\left(F_{m}\right)$ was recorded after a $0.8 \mathrm{~s}$ saturating light pulse $\left(2800 \mu \mathrm{mol} \cdot \mathrm{m}^{-2} \cdot \mathrm{s}^{-1}\right)$. Actinic light $\left(340 \mu \mathrm{mol} \cdot \mathrm{m}^{-2} \cdot \mathrm{s}^{-1}\right)$ was then applied for 3 min to drive photosynthesis. Maximum fluorescence in the light-saturated stage $\left(F_{m}^{\prime}\right)$, basic fluorescence after induction $\left(F_{o}^{\prime}\right)$ and fluorescence yield in the steady state $\left(F_{S}\right)$ were determined. The actual photochemical quantum yield $\left(Y_{I I}\right)$ was calculated as $\left(F_{m}{ }^{\prime}-F\right) / F_{m}{ }^{\prime}$. The quantum yield of regulated energy dissipation $\left(Y_{N P Q}\right)$ was calculated as $1-Y_{I I}-1 /(N P Q$ $\left.+1+\mathrm{qL}\left(F_{m} / F_{O}-1\right)\right)$. The quantum yield of nonregulated energy dissipation $\left(Y_{N O}\right)$ was calculated as $1 /\left(\mathrm{NPQ}+1+\mathrm{qL}\left(F_{m} / F_{0}-1\right)\right)$. The photochemical quenching coefficient $(q P)$ was calculated as $\left(F_{m}^{\prime}-F_{s}\right) /\left(F^{\prime}{ }_{m}-F^{\prime}{ }_{o}\right)$, while the nonphotochemical quenching coefficient (NPQ) was calculated as $\left(F_{m}-F_{m}^{\prime}\right) / F_{m}^{\prime}=F_{m} / F_{m}^{\prime}-1$. Subsequently, the photosynthetic electron transport rate $(E T R)$ was calculated as PAR $\times \mathrm{Y}_{\text {II }} \times 0.85 \times 0.5$, where 0.5 and 0.85 are the fractions of the excitation energy distributed to PSII and the fractional light absorbance, respectively, PAR is the photosynthetically active radiation, and PSII is photosystem II.

\subsection{Chlorophyll and Carotene Content}

The third fully expanded fresh leaves from the top were picked and immediately ground and extracted with $95 \%$ ethanol under dark conditions until the leaves turned white. The absorbance of chlorophyll a ( $\mathrm{Chl} \mathrm{a})$, chlorophyll b ( $\mathrm{Chl} \mathrm{b})$ and carotene was measured with a $7230 \mathrm{G}$ spectrophotometer at $665 \mathrm{~nm}\left(\mathrm{OD}_{665}\right), 649 \mathrm{~nm}\left(\mathrm{OD}_{649}\right)$ and $470 \mathrm{~nm}$ $\left(\mathrm{OD}_{470}\right)$, respectively. The corresponding chlorophyll concentration was calculated from the measured optical density values, and the chlorophyll content was determined by using the following formula [21].

$$
\text { chlorophyll content }\left(\mathrm{mg} \cdot \mathrm{g}-{ }^{1} \mathrm{FW}\right)=\frac{C \times V \times A}{W \times 1000}
$$

where $\mathrm{C}$ is the chlorophyll concentration $\left(\mathrm{mg} \cdot \mathrm{L}^{-1}\right) ; \mathrm{V}$ is the the amount applied for the extraction $(\mathrm{mL}) ; \mathrm{A}$ is the dilution ratio; $\mathrm{W}$ is the fresh weight of the sample $(\mathrm{g})$.

\subsection{Statistical Analysis}

All measurements were based on 3 replicate plants. The statistical analysis included a 1-way analysis of variance (ANOVA), and significant differences between the means were tested using Duncan's multiple range test at 95\% confidence.

\section{Results}

\subsection{Effects of Foliage Spraying of $\mathrm{NaHSO}_{3}$ on Gas Exchange of O. violaceus}

The values of $P_{N}, g_{s}$ and $E$ in the $\mathrm{NS}_{3}$ treatment were significantly higher than those in the CK (Figure 1A,B,D). However, the values of $P_{N}, g_{s}$ and $E$ in the $\mathrm{NS}_{1}, \mathrm{NS}_{2}, \mathrm{NS}_{4}$ and CK treatments showed no significant difference. The values of $P_{N}, g_{s}$ and $E$ in the $\mathrm{NS}_{4}$ treatment were significantly lower than those in the $\mathrm{NS}_{3}$ treatment (Figure $1 \mathrm{~A}, \mathrm{~B}$ ). 


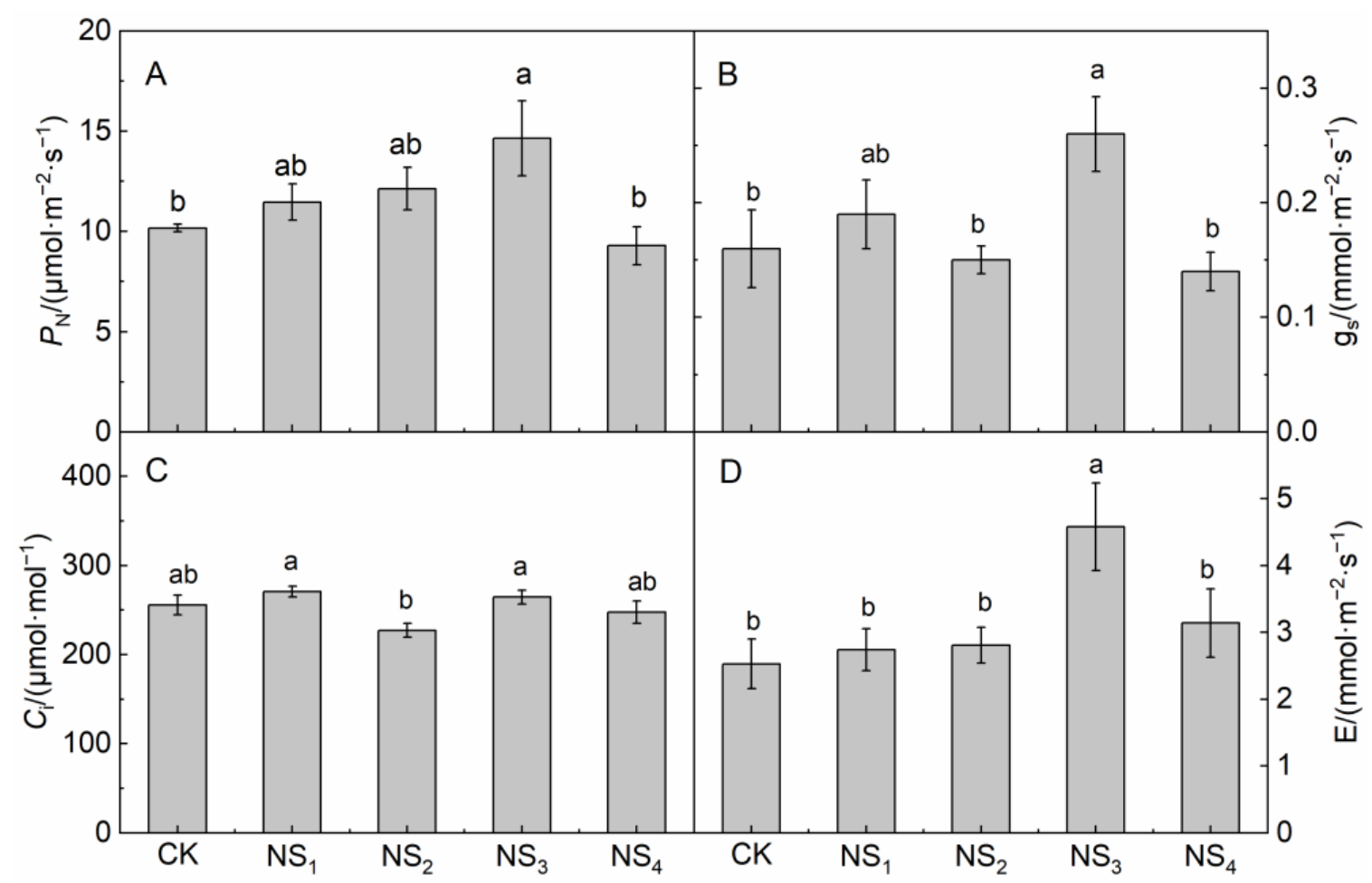

Figure 1. Effects of foliage spraying of $\mathrm{NaHSO}_{3}$ on et photosynthetic rate $\left(P_{N}\right)(\mathbf{A})$, stomatal conductance $\left(g_{s}\right)(\mathbf{B})$, intercellular carbon dioxide concentration $\left(C_{i}\right)(\mathbf{C})$, and transpiration rate $(E)(\mathbf{D})$ of $O$. violaceus. Values are the means of five repetitions \pm SE. Bars with different letters show significant differences at $p<0.05$ (Duncan).

3.2. Responses of Net Photosynthetic Rate of O. violaceus to Photosynthetically Active Radiation $(P A R)$ and Intracellular $\mathrm{CO}_{2}$ Concentration $\left(C_{i}\right)$ under Foliage Spraying of $\mathrm{NaHSO}_{3}$

The correlation coefficients $\left(R^{2}\right)$ of the $P_{N}$-PAR curve fitted by the nonrectangular hyperbolic model and the $P_{N}-C_{i}$ curve fitted by the rectangular hyperbolic model were all higher than 0.98, which indicated that the two models fit the curves mentioned above well.

Different concentrations of $\mathrm{NaHSO}_{3}$ affected the light response process differently. When the PAR was less than $200 \mu \mathrm{mol} \cdot \mathrm{m}^{-2} \cdot \mathrm{s}^{-1}$, the $P_{N}$ increased rapidly as the PAR increased, but significant differences were not observed between the values of $P_{N}$ in different treatments (Figure 2A). When the PAR was greater than $200 \mu \mathrm{mol} \cdot \mathrm{m}^{-2} \cdot \mathrm{s}^{-1}$, the $P_{N}$ value in the $\mathrm{NS}_{4}$ treatment increased more slowly than that in the CK as PAR increased. The $P_{N}$ value was significantly lower than that in the CK when the PAR reached the light saturation point (LSP). The foliar application of $10 \mathrm{mmol} \cdot \mathrm{L}^{-1}$ of $\mathrm{NaHSO}_{3}$ decreased the LSP and inhibited the photosynthetic efficiency (Figure 2A). The $P_{N}$ in the $\mathrm{NS}_{3}$ treatment exhibited a clearer increase than that in the CK as the PAR increased. The foliar application of $5 \mathrm{mmol} \cdot \mathrm{L}^{-1}$ of $\mathrm{NaHSO}_{3}$ promoted the photosynthetic capacity of $\mathrm{O}$. violaceus (Figure $2 \mathrm{~A}$ ).

Different concentrations of $\mathrm{NaHSO}_{3}$ affected the $\mathrm{CO}_{2}$ response process differently (Figure 2B). When the $\mathrm{CO}_{2}$ concentration was less than $400 \mu \mathrm{mol} \cdot \mathrm{mol}^{-1}$, the values of $P_{N}$ clearly increased as the $\mathrm{CO}_{2}$ concentration increased but slowed down when the $\mathrm{CO}_{2}$ concentration was greater than $600 \mu \mathrm{mol} \cdot \mathrm{mol}^{-1}$ (Figure 2B). The values of $P_{N}$ in the $\mathrm{NS}_{2}$ and $\mathrm{NS}_{3}$ treatments were higher than those in the $\mathrm{CK}$, and the $P_{N}$ value in the $\mathrm{NS}_{3}$ treatment was the highest. The values of $P_{N}$ in the $\mathrm{NS}_{1}$ and $\mathrm{NS}_{4}$ treatments exhibited no significant difference compared to those in the $\mathrm{CK}$ under different $\mathrm{CO}_{2}$ concentrations (Figure 2B). The photosynthetic capacity of $O$. violaceus was the highest under the foliar application of $5 \mathrm{mmol} \cdot \mathrm{L}^{-1}$ of $\mathrm{NaHSO}_{3}$, which was the optimal concentration. 

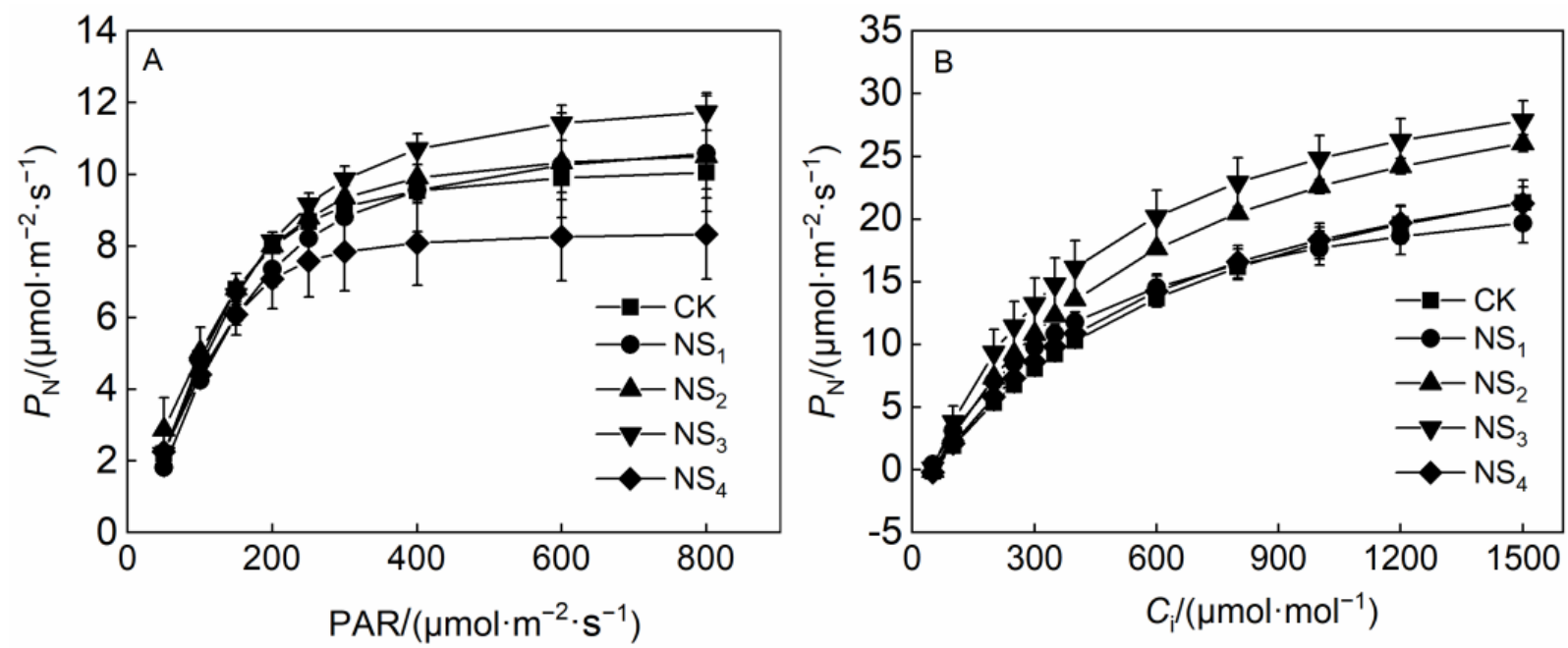

Figure 2. Net photosynthetic rate $\left(P_{N}\right)$-photosynthetically active radiation (PAR) curve (A) and net photosynthetic rate-intercellular carbon dioxide $\left(C_{i}\right)$ curve $(\mathbf{B})$ of $O$. violaceus under different concentrations of $\mathrm{NaHSO}_{3}$. Values are the means \pm SE. Symbols with different letters show significant differences at $p<0.05$ (Duncan).

Significant differences were not observed between the values of Amax and Bmax in all treatments (Table 1). The apparent quantum efficiency $(\alpha)$ is an important index that reflects the light energy utilization rate of plants [22]. The light compensation point (LCP) reflects the ability of plants to overcome their own assimilation resistance. The lower the LCP, the less the consumption of photosynthetic products and the stronger the ability to use low light intensity [23]. In this study, the values of $\alpha$ and LCP in the $\mathrm{NS}_{4}$ treatment decreased by $20.97 \%$ and $76.08 \%$ of those in the CK, respectively (Table 1 ). The O. violaceus treated with $10 \mathrm{mmol} \cdot \mathrm{L}^{-1}$ of $\mathrm{NaHSO}_{3}$ showed improvement in the ability to use weak light and lower consumption of photosynthetic products to resist the stress of high concentrations of sulfite. The initial carboxylation efficiency (CE) can reflect the activity of ribulose-1,5-bisphosphate carboxylase/oxygenase (Rubisco) and the ability of plants to utilize $\mathrm{CO}_{2}$ [24]. In this study, the value of $\mathrm{CE}$ in the $\mathrm{NS}_{3}$ treatment increased by $105.77 \%$ relative to that in the $\mathrm{CK}$, and the values in the other treatments exhibited no significant difference compared to those in the CK (Table 1).

Table 1. Photosynthetic parameters under different concentrations of $\mathrm{NaHSO}_{3}$.

\begin{tabular}{cccccc}
\hline & CK & NS $_{\mathbf{1}}$ & NS $_{\mathbf{2}}$ & NS $_{\mathbf{3}}$ & NS $_{\mathbf{4}}$ \\
\hline Amax & $11.33 \pm 0.26 \mathrm{a}$ & $12.53 \pm 2.27 \mathrm{a}$ & $11.66 \pm 1.46 \mathrm{a}$ & $13.06 \pm 0.57 \mathrm{a}$ & $8.61 \pm 1.05 \mathrm{a}$ \\
$\alpha$ & $0.062 \pm 0.00 \mathrm{a}$ & $0.055 \pm 0.01 \mathrm{a}$ & $0.058 \pm 0.01 \mathrm{~b}$ & $0.058 \pm 0.00 \mathrm{ab}$ & $0.049 \pm 0.00 \mathrm{~b}$ \\
CE & $0.052 \pm 0.00 \mathrm{~b}$ & $0.078 \pm 0.00 \mathrm{ab}$ & $0.0745 \pm 0.00 \mathrm{ab}$ & $0.107 \pm 0.02 \mathrm{a}$ & $0.059 \pm 0.01 \mathrm{~b}$ \\
Bmax & $34.92 \pm 4.03 \mathrm{ab}$ & $28.14 \pm 2.35 \mathrm{~b}$ & $40.19 \pm 1.28 \mathrm{a}$ & $41.02 \pm 0.51 \mathrm{a}$ & $33.31 \pm 1.46 \mathrm{ab}$ \\
LSP & $314.28 \pm 8.87 \mathrm{a}$ & $370.24 \pm 35.24 \mathrm{a}$ & $327.22 \pm 35.43 \mathrm{a}$ & $344.00 \pm 7.09 \mathrm{a}$ & $287.31 \pm 8.75 \mathrm{a}$ \\
LCP & $14.09 \pm 0.59 \mathrm{ab}$ & $17.78 \pm 2.74 \mathrm{a}$ & $14.12 \pm 1.62 \mathrm{ab}$ & $9.88 \pm 0.41 \mathrm{~b}$ & $3.37 \pm 0.54 \mathrm{c}$ \\
CSP & $1410.10 \pm 75.77 \mathrm{a}$ & $919.69 \pm 12.95 \mathrm{~b}$ & $1203.71 \pm 27.46 \mathrm{ab}$ & $1110.06 \pm 249.37 \mathrm{ab}$ & $1292.54 \pm 109.82 \mathrm{ab}$ \\
CCP & $52.97 \pm 7.49 \mathrm{a}$ & $42.63 \pm 0.23 \mathrm{a}$ & $51.64 \pm 3.32 \mathrm{a}$ & $49.83 \pm 8.29 \mathrm{a}$ & $54.78 \pm 5.08 \mathrm{a}$ \\
\hline
\end{tabular}

Note: Amax: maximum photosynthetic value of $P_{N}$-PAR curve; $\alpha$ : apparent quantum efficiency; $C E$ : initial carboxylation efficiency; Bmax: maximum photosynthetic value of $P_{N}-C_{i}$ curve; LSP: light saturation point; LCP: light compensation point; CSP: $\mathrm{CO}_{2}$ saturation point; CCP: $\mathrm{CO}_{2}$ compensation point; Values are the means \pm SE. Bars with different letters show significant differences at $p<0.05$ (Duncan).

As the $\mathrm{NaHSO}_{3}$ concentration increased, the values of the total respiratory rate $\left(R_{t}\right)$ initially increased and then decreased in the $\mathrm{NS}_{4}$ treatment and the value of $R_{t}$ in the $\mathrm{NS}_{3}$ treatment increased by $80.63 \%$ compared with that in the CK (Figure 3B). The values of the photorespiration rate $\left(R_{p}\right)$ and $R_{t}$ in each treatment showed the same change trends as follows: $\mathrm{NS}_{3}>\mathrm{NS}_{2}>\mathrm{NS}_{4}>\mathrm{NS}_{1}>\mathrm{CK}$ (Figure 3A,B). The values of the photorespiration rate $\left(R_{d}\right)$ gradually decreased as the $\mathrm{NaHSO}_{3}$ concentration increased, and the value in 
the $\mathrm{NS}_{4}$ treatment decreased by $85.56 \%$ of that in the CK (Figure $3 \mathrm{~A}$ ). The values of the photorespiratory portion $\left(S_{p}\right)$ gradually increased, and the value in the $\mathrm{NS}_{4}$ treatment increased by $53.85 \%$ of that in the CK (Figure $3 \mathrm{~A}$ ).

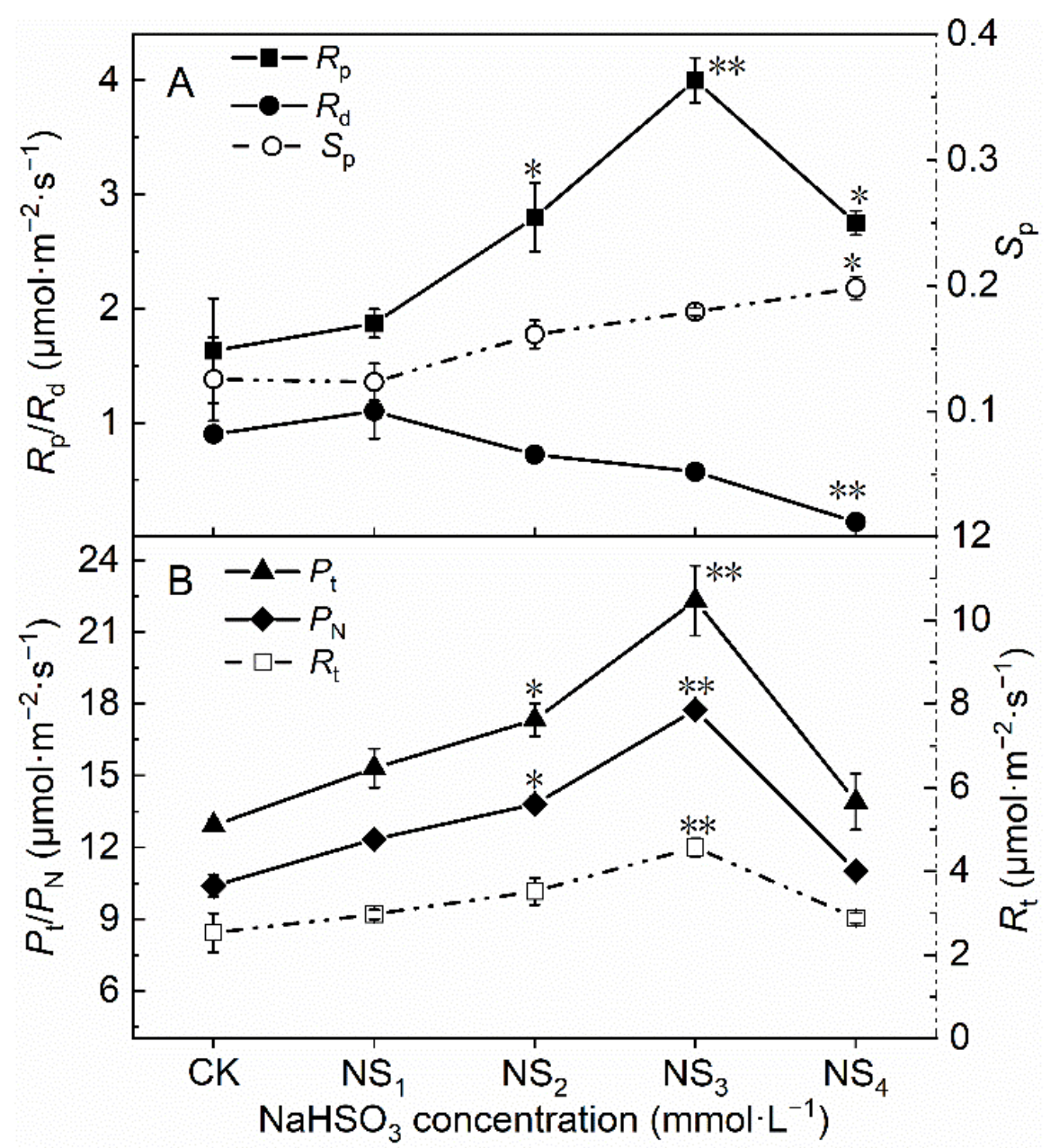

Figure 3. Photorespiration related parameters ((A): $R_{p}, R_{d}$ and $S_{p} ;(\mathbf{B}): P_{t}, P_{N}$ and $\left.R_{\mathrm{t}}\right)$ under different concentrations of $\mathrm{NaHSO}_{3}$. Significant differences between the control and treatment groups are indicated by asterisks $\left({ }^{*} p<0.05,{ }^{* *} p<0.01\right) . R_{\mathrm{d}}$ : the dark respiration rate; $R_{p}$ : the photorespiration rate; $S_{p}$ : the photorespiratory portion; $P_{N}$ : the net photosynthetic rate; $P_{t}$ : the total photosynthetic rate; $R_{t}$ : the total respiratory rate.

\subsection{Effects of Foliage Spraying of $\mathrm{NaHSO}_{3}$ on Chlorophyll Content in Leaves of O. violaceus}

Chlorophyll is a necessary molecule for the photosynthesis of plants. The $\mathrm{NS}_{1}, \mathrm{NS}_{2}$ and $\mathrm{NS}_{3}$ treatments promoted the synthesis of chlorophyll a and $\mathrm{b}$ in O. violaceus (Table 2). The chlorophyll $\mathrm{b}$ contents in the $\mathrm{NS}_{4}$ treatment had no significant difference compared with those in the CK (Table 2). The chlorophyll a, chlorophyll b and total chlorophyll contents in the $\mathrm{NS}_{4}$ treatment were slightly lower than those in the $\mathrm{NS}_{1}, \mathrm{NS}_{2}$ and $\mathrm{NS}_{3}$ treatments (Table 2). The chlorophyll a/b in each treatment had no significant difference compared with that in the $\mathrm{CK}$ (Table 2). The $\mathrm{NaHSO}_{3}$ promoted the synthesis of chlorophyll in $O$. violaceus as a synchronous change of chlorophyll a and chlorophyll b. There was no significant difference in carotenoids between the CK and other treatments (Table 2). 
Table 2. Effects of foliage spraying of $\mathrm{NaHSO}_{3}$ on chlorophyll content in O. violaceus leaves.

\begin{tabular}{cccccc}
\hline Treatment & $\begin{array}{c}\text { Chlorophyll a } \\
/\left(\mathbf{m g} \cdot \mathbf{g}^{-\mathbf{1}} \mathbf{F W}\right)\end{array}$ & $\begin{array}{c}\text { Chlorophyll b } \\
/\left(\mathbf{m g} \cdot \mathbf{g}^{-\mathbf{1}} \mathbf{F W}\right)\end{array}$ & $\begin{array}{c}\text { Chlorophyll(a }+ \\
\mathbf{b}) /\left(\mathbf{m g} \cdot \mathbf{g}^{-\mathbf{1}} \mathbf{F W}\right)\end{array}$ & Chlorophyll a/b $^{\text {Carotenoid }}$ & $\begin{array}{c}\text { Car } \\
/\left(\mathbf{m g} \cdot \mathbf{g}^{-\mathbf{1}} \mathbf{F W}\right)\end{array}$ \\
\hline $\mathrm{CK}$ & $0.812 \pm 0.026 \mathrm{~b}$ & $0.323 \pm 0.019 \mathrm{~b}$ & $1.135 \pm 0.041 \mathrm{~b}$ & $2.525 \pm 0.104 \mathrm{a}$ & $0.141 \pm 0.008 \mathrm{a}$ \\
$\mathrm{NS}_{1}$ & $1.074 \pm 0.046 \mathrm{a}$ & $0.445 \pm 0.040 \mathrm{a}$ & $1.582 \pm 0.074 \mathrm{a}$ & $2.459 \pm 0.182 \mathrm{a}$ & $0.173 \pm 0.018 \mathrm{a}$ \\
$\mathrm{NS}_{2}$ & $1.099 \pm 0.069 \mathrm{a}$ & $0.440 \pm 0.022 \mathrm{a}$ & $1.540 \pm 0.120 \mathrm{a}$ & $2.526 \pm 0.059 \mathrm{a}$ & $0.159 \pm 0.019 \mathrm{a}$ \\
$\mathrm{NS}_{3}$ & $1.134 \pm 0.076 \mathrm{a}$ & $0.440 \pm 0.048 \mathrm{a}$ & $1.574 \pm 0.261 \mathrm{a}$ & $2.648 \pm 0.182 \mathrm{a}$ & $0.177 \pm 0.014 \mathrm{a}$ \\
$\mathrm{NS}_{4}$ & $1.038 \pm 0.049 \mathrm{a}$ & $0.394 \pm 0.013 \mathrm{ab}$ & $1.432 \pm 0.122 \mathrm{a}$ & $2.632 \pm 0.061 \mathrm{a}$ & $0.157 \pm 0.009 \mathrm{a}$ \\
\hline
\end{tabular}

Note: Values are the means \pm SE. Bars with different letters show significant differences at $p<0.05$ (Duncan).

\subsection{Effect of Foliage Spraying of $\mathrm{NaHSO}_{3}$ on Chlorophyll a Fluorescence Parameters of O. violaceus Leaves}

The light energy absorbed by the PSII reaction center is mainly distributed into three parts: photochemical pathway $\left(\mathrm{Y}_{\mathrm{II}}\right)$, energy used for photoprotection mechanism $\left(\mathrm{Y}_{\mathrm{NPQ}}\right)$ and other nonphotochemical energy $\left(\mathrm{Y}_{\mathrm{NO}}\right)$ and $\mathrm{Y}_{\mathrm{II}}+\mathrm{Y}_{\mathrm{NPQ}}+\mathrm{Y}_{\mathrm{NO}}=1$ [25]. With increasing $\mathrm{NaHSO}_{3}$ concentrations, the value of $\mathrm{Y}_{\text {II }}$ gradually increased. The value in the $\mathrm{NS}_{3}$ treatment increased by $17.95 \%$ of that in the $\mathrm{CK}$, and thereafter, a decreasing trend was observed (Table 3). However, $\mathrm{Y}_{\mathrm{NPQ}}$ is the opposite of $\mathrm{Y}_{\mathrm{II}}$ and showed an initial decrease and then an increase. In the $\mathrm{NS}_{3}$ treatment, $\mathrm{Y}_{\mathrm{NPQ}}$ decreased by $16.28 \%$ relative to that in the $\mathrm{CK}$, although the value of $Y_{\mathrm{NO}}$ in each treatment had no significant difference compared with that in the CK (Table 3). Photochemical quenching (qP) and nonphotochemical quenching (NPQ) are two forms of energy dissipation in chloroplasts [26]. qP is the part of light energy used for photochemical electron transfer, which reflects the utilization of light energy to a certain extent, while NPQ is the part where excess light energy is dissipated in the form of heat energy [26]. The values of NPQ in the $\mathrm{NS}_{2}$ and $\mathrm{NS}_{3}$ treatments decreased by $26.09 \%$ and $17.39 \%$ of those in the CK, respectively, while the values of $\mathrm{qP}$ in $\mathrm{NS}_{2}$ and $\mathrm{NS}_{3}$ increased by $18.57 \%$ and $14.29 \%$ of those in the CK, respectively (Table 3 ). The values of $\mathrm{NPQ}$ and $\mathrm{qP}$ in the $\mathrm{NS}_{4}$ treatment exhibited no significant difference compared to those in the $\mathrm{CK}$. The reduction in the photochemical reaction in the $\mathrm{NS}_{4}$ treatment might be due to the excessive $\mathrm{NaHSO}_{3}$ stress on O. violaceus, which would offset the appropriate amount of $\mathrm{NaHSO}_{3}$ to promote the photochemical pathway. The apparent photosynthetic electron transport rate (ETR) mainly reflects the electron transport in the PS II reflection center [27]. The value of ETR in the $\mathrm{NS}_{4}$ treatment decreased by $18.90 \%$ of that in the CK, while the values in other treatments showed no significant difference compared with those in the CK.

Table 3. Effects of foliage spraying of $\mathrm{NaHSO}_{3}$ on chlorophyll $a$ fluorescence parameters in O. violaceus leaves.

\begin{tabular}{ccccccc}
\hline Treatment & $\mathbf{Y}_{\text {II }}$ & $\mathbf{Y}_{\text {NPQ }}$ & $\mathbf{Y}_{\text {NO }}$ & NPQ & qP & ETR \\
\hline $\mathrm{CK}$ & $0.39 \pm 0.015 \mathrm{bc}$ & $0.43 \pm 0.014 \mathrm{a}$ & $0.18 \pm 0.021 \mathrm{a}$ & $0.46 \pm 0.021 \mathrm{a}$ & $0.70 \pm 0.020 \mathrm{bc}$ & $23.49 \pm 1.064 \mathrm{ab}$ \\
$\mathrm{NS}_{1}$ & $0.39 \pm 0.033 \mathrm{bc}$ & $0.43 \pm 0.038 \mathrm{a}$ & $0.18 \pm 0.198 \mathrm{a}$ & $0.45 \pm 0.057 \mathrm{a}$ & $0.72 \pm 0.037 \mathrm{abc}$ & $21.91 \pm 1.844 \mathrm{bc}$ \\
$\mathrm{NS}_{2}$ & $0.45 \pm 0.021 \mathrm{ab}$ & $0.36 \pm 0.017 \mathrm{~b}$ & $0.19 \pm 0.020 \mathrm{a}$ & $0.34 \pm 0.020 \mathrm{~b}$ & $0.83 \pm 0.061 \mathrm{a}$ & $25.31 \pm 1.165 \mathrm{ab}$ \\
$\mathrm{NS}_{3}$ & $0.46 \pm 0.06 \mathrm{a}$ & $0.36 \pm 0.01 \mathrm{~b}$ & $0.18 \pm 0.016 \mathrm{a}$ & $0.38 \pm 0.016 \mathrm{ab}$ & $0.80 \pm 0.010 \mathrm{ab}$ & $26.09 \pm 0.337 \mathrm{a}$ \\
$\mathrm{NS}_{4}$ & $0.34 \pm 0.008 \mathrm{c}$ & $0.47 \pm 0.004 \mathrm{a}$ & $0.19 \pm 0.024 \mathrm{a}$ & $0.48 \pm 0.024 \mathrm{a}$ & $0.63 \pm 0.030 \mathrm{c}$ & $19.05 \pm 0.447 \mathrm{c}$ \\
\hline
\end{tabular}

Note: $\mathrm{Y}_{\mathrm{II}}$ : actual photochemical quantum yield; $\mathrm{Y}_{\mathrm{NPQ}}$ : quantum yield of regulated energy dissipation; $\mathrm{Y}_{\mathrm{NO}}$ : quantum yield of nonregulated energy dissipation; NPQ: nonphotochemical quenching; ETR: electron transport efficiency; Values are the means \pm SE. Bars with different letters show significant differences at $p<0.05$ (Duncan).

\section{Discussion}

Sulfur is an essential mineral element for plants, and it is fourth in the list of major plant nutrients after nitrogen, phosphorus and potassium [28]. Higher plants mainly uptake inorganic sulfate from the soil by their roots, and they can also absorb the atmospheric $\mathrm{SO}_{2}$ and exogenous $\mathrm{HSO}_{3}{ }^{-}, \mathrm{SO}_{3}{ }^{-}$and $\mathrm{S}^{2-}$ through leaf stomata. During the process of sulfur metabolism, exogenous sulfur is first converted into the form of sulfate $\left(\mathrm{SO}_{4}{ }^{2-}\right)$, which can be absorbed by plants. After activation and reduction, sulfite $\left(\mathrm{SO}_{3}{ }^{2-}\right)$ can be produced, which has potential cytotoxicity [29]. Many metabolic pathways of $\mathrm{SO}_{3}{ }^{2-}$ 
are observed in plants, and their metabolites are closely related to chlorophyll synthesis. First, $\mathrm{SO}_{3}{ }^{2-}$ is reduced to sulfide $\left(\mathrm{S}^{2-}\right)$ under the action of sulfite reductase and $\mathrm{S}^{2-}$ reacts with acetylserine (OAS) to form cysteine (Cys) [30]. As the precursor of sulfur-containing amino acids, Cys is further synthesized into various sulfur-containing proteins, thus guaranteeing the early synthesis of chlorophyll; then, $\mathrm{SO}_{3}{ }^{2-}$ in chloroplasts could enter the thiolipid reduction pathway to synthesize sulfoquinovosyldiacylglycerol (SQDG) through two consecutive steps. SQDG is a sulfur-containing nonphosphorus glycerolipid that participates in the formation of the granum lamellae of chloroplasts, and its content is positively correlated with the chlorophyll concentration in the process of chloroplast dedifferentiation and regeneration [31]. Although sulfur is not the main component of chlorophyll, it obviously affects the synthesis of chlorophyll. It is noteworthy that the variation of chlorophyll content will directly affect the absorption, transformation and utilization of light energy by plants [32]. Ribulose-1,5-bisphosphate (RuBP) carboxylase/oxygenase (Rubisco) catalyzes the first step of the reaction of $\mathrm{CO}_{2}$ assimilation and photorespiration carbon oxidation in photosynthesis and is considered the main factor controlling the rate of photosynthesis. To ensure its catalytic ability, Rubisco must be activated by Rubisco activase (RCA). Studies have found that $\mathrm{NaHSO}_{3}$ could promote the expression of RCA genes at the transcription and translation levels, thus enhancing the initial activity of Rubisco in plants [33]. RCA activity was sensitive to the ATP/ADP ratio observed in the chloroplast matrix, and the activation of RCA depended on the hydrolysis of ATP and was inhibited by ADP [34]. Wang et al. [35] reported that $1 \mathrm{mmol} \cdot \mathrm{L}^{-1}$ of $\mathrm{NaHSO}_{3}$ acted similarly as phenazine methyl sulfate (PMS), a cofactor that catalyzed cyclic photophosphorylation, by promoting photophosphorylation and increasing the ATP supply, thereby maintaining high levels of photosynthesis. Moreover, $5 \mathrm{mmol} \cdot \mathrm{L}^{-1}$ of $\mathrm{NaHSO}_{3}$, as a sulfur source absorbed and utilized by plants, may play an active role in O. violaceus. On the one hand, the increase in $\mathrm{HSO}_{3}{ }^{-}$in the leaves accelerated the metabolism of sulfate, and its metabolites directly or indirectly promoted the increase in chlorophyll content, which was conducive to the absorption of light energy by the treated leaves, which was consistent with the results of Li et al. [36]. Meanwhile, the ratio of light energy to the photochemical pathway and light protection mechanism was adjusted. As a result, more light energy was allocated to the photochemical pathway $\left(\mathrm{Y}_{\mathrm{II}}\right.$ increased significantly, while $\mathrm{Y}_{\mathrm{NPQ}}$ decreased significantly), the light energy utilization rate increased and the final photosynthetic rate increased. On the other hand, $\mathrm{NaHSO}_{3}$ may increase the expression of RCA genes by promoting photophosphorylation and increasing the supply of ATP, thus increasing the initial activity of Rubisco, which can catalyze the two reactions of RuBP carboxylation (photosynthesis) and oxidation (photorespiration) simultaneously, and the photosynthetic rate and photorespiration rate increase synchronously.

Photorespiration is a process in which plants fix oxygen and release $\mathrm{CO}_{2}$ under light conditions. Photorespiration can alleviate photoinhibition, eliminate toxic intermediate products and provide raw materials for other metabolic activities, and it plays an active role in photosynthesis [37]. Studies have suggested that the activities of RuBP carboxylase and RuBP oxygenase in high-yield genotype wheat were higher than those in low-yield genotype wheat. High photosynthesis and photorespiration intensities are important preconditions for ensuring high wheat yield [38]. The electron transport rate of PSII and ATP production increased when a low concentration of $\mathrm{NaHSO}_{3}$ was sprayed on citrus leaves, which decreased photoinhibition and thereby increased the net photosynthetic rate [12]. Foliage sprayed with an appropriate concentration of $\mathrm{NaHSO}_{3}$ increased the total photosynthetic and photorespiration rates, which was consistent with the results reported in the studies mentioned above. Photorespiration consumed excess light energy and protected the photosynthetic apparatus when the consumption ratio of photorespiration to photosynthate was maintained, which indirectly maintained photosynthesis. However, photorespiration consumes photosynthetic products without producing ATP, and it has also been considered a negative factor in photosynthesis. Stomata are important channels for $\mathrm{CO}_{2}$ and water exchange between plants and the environment [39]. In this 
study, the stomatal conductance of $O$. violaceus leaves in the $\mathrm{NS}_{4}$ treatment decreased, which may be due to the stress caused by higher concentrations of $\mathrm{NaHSO}_{3}$. To respond to the deficiency of water and $\mathrm{CO}_{2}$ caused by the decrease in stomatal conductance, the gene expression of carbonic anhydrase (CA) in leaves is upregulated, which catalyzes the conversion of intracellular $\mathrm{HCO}_{3}{ }^{-}$into $\mathrm{H}_{2} \mathrm{O}$ and $\mathrm{CO}_{2}$ [40]. The contents of chlorophyll a and $\mathrm{b}$, the electron transport rate and the photosynthetic rate of soybean all reportedly increased when the leaves were sprayed with an appropriate concentration of $\mathrm{HCO}_{3}{ }^{-}$[41]. This demonstrated that the effect of $\mathrm{HCO}_{3}{ }^{-}$on plants was similar to that of $\mathrm{HSO}_{3}{ }^{-}$in this study. One possible hypothesis was that competition may occur between $\mathrm{HCO}_{3}{ }^{-}$ and $\mathrm{HSO}_{3}{ }^{-}$in the process of photosynthesis due to their similar structure. Under highconcentration $\mathrm{NaHSO}_{3}$ treatment, excessive $\mathrm{HSO}_{3}{ }^{-}$accumulated in the cell sap to compete with $\mathrm{HCO}_{3}{ }^{-}$for the active site of $\mathrm{CA}$, thereby hindering the combination of $\mathrm{HCO}_{3}{ }^{-}$and CA. Plants could not offset the deficiency of $\mathrm{H}_{2} \mathrm{O}$ and $\mathrm{CO}_{2}$ in their leaves by converting intracellular $\mathrm{HCO}_{3}{ }^{-}$when stomatal conductance decreased. The carboxylation of RuBP was inhibited, and the total photosynthetic rate decreased. In addition, $O$. violaceus would suffer from stress when they were sprayed with high concentrations of $\mathrm{NaHSO}_{3}$ (the reason for stress will be explained later). A high photorespiration rate and $S_{p}$ in plants had a protective effect against photosynthetic apparatus damage in response to stress conditions, while a high proportion of photorespiration would also consume photosynthates and therefore decrease the net photosynthetic rate.

Among sulfites, the valence of sulfur is +4 , which is both reducing and oxidizing. Sulfite dissolved in water can not only obtain electrons to form sulfur precipitates but also lose electrons to form sulfates: $\mathrm{SO}_{3}{ }^{2-}+3 \mathrm{H}_{2} \mathrm{O}+4 \mathrm{e}^{-} \rightleftharpoons \mathrm{S}+6 \mathrm{OH}^{-} \mathrm{E}=-0.66$; $\mathrm{SO}_{3}{ }^{2-}+\mathrm{H}_{2} \mathrm{O}-2 \mathrm{e}^{-} \rightleftharpoons \mathrm{SO}_{4}{ }^{2-}+2 \mathrm{H}^{+} \mathrm{E}=+0.2$. Sulfite in plants has both reduction and oxidation properties, and it has dual effects on plant photosynthesis due to its concentration, which is protective or inhibitory. As a nucleophilic substance, sulfite can attack diverse substrates by splitting the disulfide bonds into peptides and cause inactivation of these compounds, which is called sulfitolysis. Sulfitolysis can lead to chlorophyll destruction, photosynthesis suppression, necrotic damage and growth retardation [42]. Therefore, if sulfite accumulates in plants and cannot be metabolized rapidly, it will cause serious damage at the cellular and even the entire plant level [30]. Sulfate oxidase (SO) plays a vital role in relieving this toxicity, and it can serve as a 'safety valve' to detoxify excess amounts of sulfite and protect the cells from sulfitolysis [43]. Wei et al. [44] found that an appropriate amount of $\mathrm{NaHSO}_{3}$ could react with the superoxide anion produced by the PSI receptor of Chlamydomonas reinhardtii; as a result, an anaerobic environment was established, hydrogenase $\left(\mathrm{H}_{2}\right.$ ase $)$ was activated and the hydrogen production capacity was significantly improved. Golan and Whitaker [45] also proved that $\mathrm{NaHSO}_{3}$ could be used as a reducing agent to inhibit the activity of mushroom polyphenol oxidase (PPO), thereby playing a certain role in preventing browning. Therefore, $\mathrm{NaHSO}_{3}$ had a certain degree of reducibility. At appropriate concentrations, it oxidized into sulfate to enter sulfate metabolism, and it detoxified or reacted with active oxygen to reduce the damage of strong oxidizing substances to cells. However, when the concentration of $\mathrm{NaHSO}_{3}$ increased to a certain extent, its oxidation led to adverse impacts on plants. Lüttge et al. [18] indicated that a certain concentration of bisulfite compounds interfered with membrane proteins and lipids, which impaired membrane integrity and inhibited photosynthetic $\mathrm{CO}_{2}$ fixation and ion transport processes. Lin et al. [46] reported that the active oxygen content in the leaves of rice seedlings increased significantly as the $\mathrm{NaHSO}_{3}$ concentration increased. Chlorophyll $a$ fluorescence technology is often used to study photosynthesis under adversity $[47,48]$. In this study, the ETR and $\mathrm{Y}_{\mathrm{II}}$ in the $\mathrm{NS}_{4}$ treatment decreased significantly compared to those in the $\mathrm{NS}_{3}$ treatment, while the $\mathrm{Y}_{\mathrm{NPQ}}$ increased. The results demonstrated that the leaves of $\mathrm{O}$. violaceus suffered from mild stress when they were sprayed with $10 \mathrm{mmol} \cdot \mathrm{L}^{-1}$ of $\mathrm{NaHSO}_{3}$. Excessive $\mathrm{HSO}_{3}{ }^{-}$not only had oxidative properties but also induced the production of active oxygen. These strong oxidizing substances attacked the cell biofilm system of plants, injured the photosynthetic apparatus and even a variety of 
organelles and affected the processes of photosynthetic $\mathrm{CO}_{2}$ absorption and ion transport, thereby inhibiting the photosynthetic carbon assimilation and reducing the efficiency of photosynthetic electron transport. To avoid further damage to plants caused by excess light energy, plants need to convert part of the captured light energy into heat energy through a heat dissipation mechanism. Physiological activities, such as protein synthesis, nutrient absorption and transport were affected under stress, which reduced the dark respiration rate.

\section{Conclusions}

The $5 \mathrm{mmol} \cdot \mathrm{L}^{-1}$ of $\mathrm{NaHSO}_{3}$ was the appropriate concentration, which promoted the photosynthetic capacity and increased production, while a concentration of $10 \mathrm{mmol} \cdot \mathrm{L}^{-1}$ inhibited the photosynthesis and caused pollution of O. violaceus. Photorespiration had a certain protective effect on plants that suffered from stress, but an excessive photorespiration portion consumed photosynthates and decreased the net photosynthetic rate. $5 \mathrm{mmol} \cdot \mathrm{L}^{-1}$ of $\mathrm{NaHSO}_{3}$ absorbed by plants could be considered a sulfur source. The results helped to better understand the dose effect of $\mathrm{HSO}_{3}{ }^{-}$on plant photosynthetic physiology, which provided a theoretical basis for the reasonable utilization of $\mathrm{NaHSO}_{3}$ and promotion of agricultural production.

Author Contributions: Conceptualization, Z.L. and Y.W.; methodology, Z.L., D.X. and Y.W.; validation, K.Z., J.X. and R.Y.; resources, Z.L.; data curation, T.C. and R.D.; writing-original draft preparation, Z.L.; writing — review and editing, D.X. and Y.W.; project administration, Z.L.; funding acquisition, Y.W. All authors have read and agreed to the published version of the manuscript.

Funding: This research was funded by by the project of the National Key Research and Development Program of China [2016YFC0502602], the National Natural Science Foundation of China [No. U1612441], Support Plan Projects of Science and Technology Department of Guizhou Province [No. (2021)YB453].

Institutional Review Board Statement: Not applicable.

Informed Consent Statement: Not applicable.

Data Availability Statement: The datasets during or analyzed during the current study available from the corresponding author on reasonable request.

Conflicts of Interest: The authors declare no conflict of interest. The funders had no role in the design of the study.

\section{References}

1. Zhang, Y.; Ji, H.B. Physiological responses and accumulation characteristics of turfgrasses exposed to potentially toxic elements. J. Environ. Manag. 2019, 246, 796-807. [CrossRef] [PubMed]

2. Xing, D.K.; Wu, Y.Y.; Fu, W.G.; Li, Q.L.; Wu, Y.S. Regulated deficit irrigation scheduling of Orychophragmus violaceus based on photosynthetic physiological response traits. Trans. ASABE 2016, 59, 1853-1860.

3. Bayat, L.; Askari, M.; Amini, F.; Zahedi, M. Effects of Rhizobium inoculation on Trifolium resupinatum antioxidant system under sulfur dioxide pollution. Biol. J. Microb. 2014, 2, 37-50.

4. Katainen, H.S.; Mäkinen, E.; Jokinen, J.; Kellomäki, S. Effects of $\mathrm{SO}_{2}$ on the photosynthetic and respiration rates in scots pine seedlings. Environ. Pollut. 1987, 46, 241-251. [CrossRef]

5. Tombuloglu, H.; Ablazov, A.; Filiz, E. Genome-wide analysis of response to low sulfur (LSU) genes in grass species and expression profiling of model grass species Brachypodium distachyon under S deficiency. Turk. J. Biol. 2016, 40, 934-943. [CrossRef]

6. Yang, S.L.; Wang, J.; Cong, W.; Cai, Z.L.; Ouyang, F. Effects of bisulfite and sulfite on the microalga Botryococcus braunii. Enzym. Microb. Technol. 2004, 35, 46-50. [CrossRef]

7. Kang, T.; Wu, H.D.; Lu, B.Y.; Luo, X.J.; Gong, C.M.; Bai, J. Low concentrations of glycine inhibit photorespiration and enhance the net rate of photosynthesis in Caragana korshinskii. Photosynthetica 2018, 56, 512-519. [CrossRef]

8. Chen, G.K.; Wang, X.Y.; Kang, H.J.; Sun, J. Effect of different $\mathrm{NaHSO}_{3}$ concentrations on gas exchange and fluorescence parameters in beans and maize. J. Nucl. Agr. Sci. 2017, 31, 379-385. (In Chinese)

9. Guo, Y.P.; Hu, M.J.; Zhou, H.F.; Zhang, L.C.; Su, J.H.; Wang, H.W.; Shen, Y.G. Different pathways are involved in the enhancement of photosynthetic rate by sodium bisulfite and benzyladenine, a case study with strawberry (Fragaria $\times$ Ananassa Duch) plants. Plant Growth Regul. 2006, 48, 65-72. [CrossRef] 
10. Wang, L.; Ming, C.; Wei, L.; Gao, F.; Lv, Z.; Wang, Q.; Ma, W. Treatment with moderate concentrations of $\mathrm{NaHSO}_{3}$ enhances photobiological H production in the cyanobacterium Anabaena sp. strain PCC 7120. Int. J. Hydrogen Energy 2010, 35, 12777-12783. [CrossRef]

11. Wang, H.; Mi, H.; Ye, J.; Deng, Y.; Shen, Y. Low concentrations of $\mathrm{NaHSO}_{3}$ increase cyclic photophosphorylation and photosynthesis in cyanobacterium Synechocystis PCC 6803. Photosynth. Res. 2003, 75, 151-159. [CrossRef] [PubMed]

12. Guo, Y.P.; Hu, M.J.; Zhou, H.F.; Zhang, L.C.; Su, J.H.; Wang, H.W.; Shen, Y.G. Low concentrations of $\mathrm{NaHSO}_{3}$ increase photosynthesis, biomass, and attenuate photoinhibition in Satsuma mandarin (Citrus unshiu Marc.) plants. Photosynthetica 2006, 44, 333-337. [CrossRef]

13. Busch, F.A. Photorespiration in the context of Rubisco biochemistry, $\mathrm{CO}_{2}$ diffusion and metabolism. Plant J. 2020, 101, 919-939. [CrossRef] [PubMed]

14. Veeranjaneyulu, K.; Charlebois, D.; Soukpoé-Kossi, C.N.; Leblanc, R.M. Sulfite inhibition of photochemical activity of intact pea leaves. Photosynth. Res. 1992, 34, 271-278. [CrossRef]

15. Galina, B.; Dmiry, Y.; Albert, B.; Vladislav, G.; Lnna, G.K.; Aaron, F.; Rachel, A.; Robert, F.; Moshe, S. Sulfite oxidase activity is essential for normal sulfur, nitrogen and carbon metabolism in tomato leaves. Plants 2015, 4, 573-605.

16. Queval, G.; Foyer, C.H. Redox regulation of photosynthetic gene expression. Philos. Trans. R. Soc. B 2012, 367, 3475-3485. [CrossRef] [PubMed]

17. Wei, L.; Yi, J.; Wang, L.; Huang, T.; Gao, F.; Wang, Q.; Ma, W. Light intensity is important for hydrogen production in $\mathrm{NaHSO}_{3}$ treated Chlamydomonas reinhardtii. Plant Cell Physiol. 2017, 58, 451-457.

18. Lüttge, U.; Osmond, C.B.; Ball, E.; Brinckmann, E.; Kinze, G. Bisulfite compounds as metabolic inhibitors: Nonspecific effects on membranes. Plant Cell Physiol. 1972, 13, 505-514.

19. Ye, Z.P. A review on modeling of responses of photosynthesis to light and $\mathrm{CO}_{2}$. Chin. J. Plant Ecol. 2010, 34, 727-740. (In Chinese)

20. Wu, Y.Y.; Rao, S.; Zhang, K.Y.; Lu, Y.; Zhao, L.H.; Liang, Z. A Quantitative Method for Determining the Portion of Photorespiratory Pathway in Plants. China Patent 2016105277715, 13 February 2018.

21. Wang, J.; Lu, W.; Yu, T.; Yang, Q. Leaf morphology, photosynthetic performance, chlorophyll fluorescence, stomatal development of Lettuce (Lactuca sativa L.) exposed to different ratios of red light to blue light. Front. Plant Sci. 2016, 7, 250.

22. Herrmann, H.; Schwartz, J.M.; Johnson, G.N. From empirical to theoretical models of light response curves-Linking photosynthetic and metabolic acclimation. Photosynth. Res. 2020, 145, 5-14. [CrossRef]

23. Duan, M.; Yang, W.C.; Mao, X.M. Effects of water deficit on photosynthetic characteristics of spring wheat under plastic mulching and comparison of light response curve models. Trans. Chin. Soc. Agri. Mach. 2018, 49, 219-227. (In Chinese)

24. Ren, B.; Li, J.; Tong, X.J.; Mei, Y.M.; Meng, P.; Zhang, J.S. Simulation on photosynthetic- $\mathrm{CO}_{2}$ response of quercus variabilis and Robinia pseudoacacia in the southern foot of the Taihang Mountain, China. Chin. J. Appl. Ecol. 2018, 29, 1-10. (In Chinese)

25. Kramer, D.M.; Johnson, G.; Kiirats, O.; Edwards, G.E. New fluorescence parameters for the determination of $Q_{A}$ redox state and excitation energy fluxes. Photosynth. Res. 2004, 79, 209-218. [CrossRef] [PubMed]

26. Zai, X.M.; Zhu, S.N.; Qin, P.; Wang, X.Y.; Luo, F.X. Effect of Glomus mosseae on chlorophyll content, chlorophyll fluorescence parameters, and chloroplast ultrastructure of beach plum (Prunus maritima) under NaCl stress. Photosynthetica 2012, 50, 323-328. [CrossRef]

27. Hu, H.; Wang, L.H.; Wang, Q.Q.; Jiao, L.Y.; Hua, W.Q.; Zhou, Q.; Huang, X.H. Photosynthesis, chlorophyll fluorescence characteristics and chlorophyll content of soybean seedlings under combined stress of bisphenol A and cadmium. Environ. Toxicol. Chem. 2014, 33, 2455-2462. [CrossRef] [PubMed]

28. Anjum, N.A.; Gill, R.; Kaushik, M.; Hasanuzzaman, M.; Pereira, E.; Tuteja, N.; Gill, S.S. ATP-sulfurylase, sulfur-compounds and plant stress tolerance. Front. Plant Sci. 2015, 6, 210. [CrossRef]

29. Stanislav, K.; Mario, M.; Hideki, T. Sulfur nutrition: Impacts on plant development, metabolism, and stress responses. J. Exp. Bot. 2019, 70, 4069-4073.

30. Brychkova, G.; Grishkevich, V.; Fluhr, R.; Sagi, M. An essential role for tomato sulfite oxidase and enzymes of the sulfite network in maintaining leaf sulfite homeostasis. Plant Physiol. 2013, 161, 148-164. [CrossRef]

31. Krzysztof, Z. Encyclopedia of Lipidomics, 1st ed.; Springer: Dordrecht, The Netherlands, 2017; pp. 1-4.

32. Masuda, T. Recent overview of the Mg branch of the tetrapyrrole biosynthesis leading to chlorophylls. Photosynth. Res. 2008, 96, 21-143. [CrossRef]

33. Chen, Y.; Jin, J.H.; Jiang, Q.S.; Yu, C.L.; Chen, J.; Xu, L.G.; Jiang, D.A. Sodium bisulfite enhances photosynthesis in rice by inducing Rubisco activase gene expression. Photosynthetica 2014, 52, 475-478. [CrossRef]

34. Portis, A.R. Rubisco activase-Rubisco's catalytic chaperone. Photosynth. Res. 2003, 75, 11-27. [CrossRef]

35. Wang, H.W.; Wei, J.M.; Shen, Y.G. Spraying low concentration sodium bisulfite can promote the photosynthetic phosphorylation and photosynthesis of wheat leaves. Sci. Bull. 2000, 45, 394-398. (In Chinese) [CrossRef]

36. Li, J.; Liu, X.L.; Zhang, C.L.; Guan, C.Y.; Dai, L.L.; Zhang, Y.L.; Tan, L.T.; Ma, N.; Yuan, Z.J. Effects of NaHSO $_{3}$ on photosynthetic characteristics and nitrogen metabolism of rapeseed seedlings. Chin. J. Oil Crop Sci. 2014, 36, 761-769. (In Chinese)

37. Sunil, B.; Saini, D.; Bapatla, R.B.; Aswani, V.; Raghavendra, A.S. Photorespiration is complemented by cyclic electron flow and the alternative oxidase pathway to optimize photosynthesis and protect against abiotic stress. Photosynth. Res. 2019, 139, 67-69. [CrossRef] 
38. Aliyev, J.A. Photosynthesis, photorespiration and productivity of wheat and soybean genotypes. Physiol. Plant. 2012, 145, 369-383. [CrossRef] [PubMed]

39. Matthew, H.; James, H.; Mcelwain, J.C. Differences in the response sensitivity of stomatal index to atmospheric $\mathrm{CO}_{2}$ among four genera of Cupressaceae conifers. Ann. Bot. Lond. 2010, 3, 411-418.

40. Hu, H.; Boisson-Dernier, A.; Israelsson-Nordström, M.; Böhmer, M.; Xue, S.; Ries, A.; Godoski, J.; Kuhn, M.J.; Schroeder, I.J. Carbonic anhydrases are upstream regulators of $\mathrm{CO}_{2}$ controlled stomatal movements in guard cells. Nat. Cell Biol. 2010, 12, 87-93. [CrossRef]

41. Hao, J.J.; Huang, C.H.; Lu, H.; Yu, Y. Influence of $\mathrm{K}^{+}, \mathrm{Na}^{+}$and $\mathrm{HCO}_{3}{ }^{-}$on photosynthesis of soybean seedlings. Soybean Sci. 2012, 31, 436-439. (In Chinese)

42. Yarmolinsky, D.; Brychkova, G.; Fluhr, R.; Sagi, M. Sulfite reductase protects plants against sulfite toxicity. Plant Physiol. 2013, 161, 725-743. [CrossRef]

43. Hänsch, R.; Mendel, R.R. Sulfite oxidation in plant peroxisomes. Photosynth. Res. 2005, 86, 337-343. [CrossRef] [PubMed]

44. Wei, L.; Li, X.; Fan, B.; Ran, Z.; Ma, W. A stepwise $\mathrm{NaHSO}_{3}$ addition mode greatly improves $\mathrm{H}_{2}$ photoproduction in Chlamydomonas reinhardtii. Front. Plant Sci. 2018, 9, 1532. [CrossRef] [PubMed]

45. Golan, A.; Whitaker, J.R. Effect of ascorbic acid, sodium bisulfite, and thiol compounds on mushroom polyphenol oxidase. J. Agr. Food Chem. 1984, 32, 1003-1009. [CrossRef]

46. Lin, Z.F.; Liu, N.; Chen, S.W.; Lin, G.Z.; Mo, H. Bisulfite $\left(\mathrm{HSO}_{3}\right)$ hydroponics induced oxidative stress and its effect on nutrient element compositions in rice seedlings. Bot. Stud. 2011, 52, 173-181.

47. Liu, X.; Li, M.L.; Li, J.M.; Su, C.L.; Lian, S.; Zhang, H.B.; Li, Y.X.; Ge, K.; Li, L. AhGLK1 affects chlorophyll biosynthesis and photosynthesis in peanut leaves during recovery from drought. Sci. Rep. 2018, 8, 139-158. [CrossRef]

48. Ghassemi-Golezani, K.; Hosseinzadeh-Mahootchi, A.; Farhangi-Abriz, S. Chlorophyll a fluorescence of safflower affected by salt stress and hormonal treatments. SN Appl. Sci. 2020, 2, 121-158. [CrossRef] 